\title{
ОЦІНКА ВИДОВОГО СКЛАДУ МІКРОФЛОРИ ПРОСВІТУ ТОВСТОЇ КИШКИ У ЩУРІВ ПРИ БАГАТОРАЗОВОМУ ІНГАЛЯЦІЙНОМУ ВПЛИВІ НІТРОКСОЛІНУ
}

\author{
ФГ. І. Яськів, Б. П. Кузьмінов, І. Л. Платонова, І. А. Руда \\ Львівський національний медичний університет імені Данила Галицького
}

РЕЗЮМЕ. Важливим у схемі досліджень з гігієнічного обгрунтування регламентів допустимого вмісту лікарських засобів у повітрі робочої зони фармацевтичних підприємств є встановлення параметрів токсичності, алергічної, ембріотоксичної, дисбіотичної дії.

Мета - оцінка видового складу мікрофлори просвіту прямого відділу товстої кишки у щурів при багаторазовому інгаляційному впливі нітроксоліну.

Матеріал і методи. Дисбіотичну дію нітроксоліну вивчали на щурах, яких упродовж 30 днів піддавали впливу

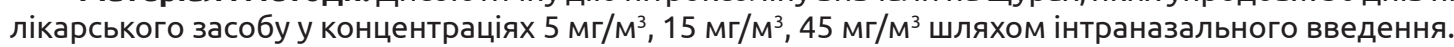

Результати. Домінантними представниками нормобіоти фекального біотопу є біфідобактерії, лактобактерії, бактерії групи кишкових паличок, зокрема E. coli, ентерококи, стафілококи, які виявляли у випорожненнях $100,0 \%$ тварин. Частота виявлення пептострептококів та стрептококів коливалася в межах 33,3 \% - 66,7 \%, протею 16,7 \% - 50,0 \%, грибів роду кандида - 16,7 \% - 33,3 \%, плісеневих грибів - 0 \% - 16,7 \%. При концентраціях нітро-

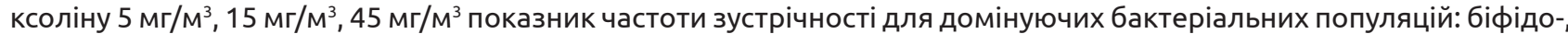
лактобактерій, БГКП, ентерококів і стафілококів залишався незмінним - 100,0 \%. Нітроксолін у концентрації 5 г/м³ не викликав змін у структурі мікробіоти кишки. Концентрації 15 мг/м³, 45 мг/м³ викликали зростання частоти виявлення умовно-патогенних штамів та зниження пептострептококів і стрептококів. Наприкінці відновного періоду частота виявлення протею, грибів роду Candida, плісеневих грибів у фекальному біотопі щурів другої (15 мг/м³) та третьої дослідної груп (45 мг/м³) утримувалися на рівні показників 4 тижня експерименту.

Висновки. Багаторазова інгаляційна дія нітроксоліну у концентрації 15 мг/м³ викликає дисбактеріоз товстої

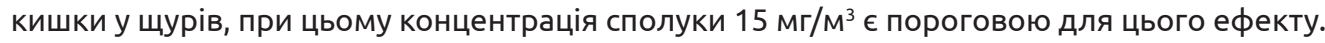

КЛючОВІ СЛОВА: нітроксолін; інгаляційний вплив; мікробіоценоз товстої кишки.

Вступ. Прояви професійної патології робітників, зайнятих на виробництві лікарських засобів (ЛЗ), загалом, повторюють побічні реакції, що спостерігаються в клінічних умовах при контактному, пероральному і інгаляційному застосуванні препаратів з лікувальною метою. В більшості випадків вони зводяться до явищ, пов'язаних 3 алергічними і токсичними реакціями та дисбіотичним ефектом [1, 2]. Тому в принципову схему досліджень з гігієнічного обгрунтування гігієнічних регламентів допустимого вмісту лікарських засобів у повітрі робочої зони обов'язково включається вивчення цих типів біологічної дії [3].

Мета - дослідити та дати оцінку видового складу мікрофлори просвіту прямого відділу товстої кишки у щурів при багаторазовому інгаляційному впливі нітроксоліну.

Матеріал і методи дослідження. Нітроксолін - синтетичний уроантисептик, ефективний щодо широкого спектра грампозитивних, грамнегативних бактерій і грибів. Спектр його антибактеріальної та протигрибкової активності поширюється на більшість мікроорганізмів, що інфікують сечовивідні шляхи. Встановлено, що $\mathrm{DL}_{50}$ нітроксоліну при пероральному надходженні в організм білих щурів-самок становить 980 мг/кг, білих щурів-самців - 835 мг/кг, білих мишей-самців - 660 мг/кг [4], що дозволяє віднести препарат до 3 класу небез- пеки (речовини помірно небезпечні) згідно з ГОСТ 12.1.007-76.

Дослідження дисбіотичної дії нітроксоліну проводили на нелінійних самках щурів, яких упродовж 30 днів піддавали впливу лікарського засобу, який вводили інтраназально у дозах, що відповідали концентраціям сполуки у повітрі: $5 \mathrm{Mr} / \mathrm{M}^{3}, 15 \mathrm{Mr} / \mathrm{M}^{3}$, $45 \mathrm{Mr} / \mathrm{M}^{3}$. У експерименті перебувало 4 групи тварин: контрольна і 3 дослідні, по 8 особин кожна, вагою 200-250 г. Тварин утримували у віварії Львівського національного медичного університету на стандартному харчовому раціоні з дотриманням принципів біоетики відповідно до положення $\epsilon_{\mathrm{B}}$ ропейської конвенції щодо захисту хребетних тварин, яких використовують в експериментальних та інших наукових цілях (Страсбург, 1986 р.), Директиви Ради Європи 2010/63/EU, Закону України № 3447-IV «Про захист тварин від жорстокого поводження", загальних етичних принципів експериментів на тваринах, ухвалених Першим національним конгресом України з біоетики (2001р.) та нормативним документом Міністерства освіти, науки, молоді та спорту України, наказ від 01.03.2012 № 249 «Порядок проведення науковими установами дослідів, експериментів на тваринах» [5]. Усіх тварин утримували в однакових умовах (температура, вологість, освітлення) відповідно до санітарно-гігієнічних вимог. 
Огляди літератури, оригінальні дослідження, погляд на проблему, ювілеї

Дослідні групи формували відповідно до кон-

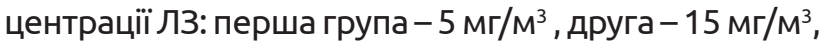
третя - $45 \mathrm{mr} / \mathrm{M}^{3}$. Мікробіологічні дослідження біотопу вмісту прямого відділу товстої кишки проводили у динаміці: до початку затруєння тварин (фон), через 2, 4 тижні та через місяць після закінчення затруєння (відновний період) [3].

Матеріалом для вивчення біотопу прямого відділу товстої кишки були свіжі випорожнення лабораторних щурів, які відбирали у стерильні пробірки. Всі мікробіологічні маніпуляції проводили з дотриманням правил асептики та антисептики. Взірці зважували, додавали 0,9 \% $\mathrm{NaCl}$ у перерахунку на 10-кратне розведення, гомогенізували, отримували вихідну пробу $10^{-1}$. 3 вихідної проби готували серію розведень до 10-10. Виявлення основних груп життєздатних мікроорганізмів (КУО) проводили шляхом висіву відповідних розведень на селективно-диференційні середовища.

Поживні середовища готували відповідно до ДСТУ 5093:2008 [6]. Контроль якості поживних середовищ проводили за рекомендаціями фірмвиробників, як зазначено у сертифікатах до продукції, згідно з Інформаційним листом МОЗ України № 05.4.1/1670 «Бактеріологічний контроль поживних середовищ", Київ, 2000.

Для виявлення біфідобактерій використовували агаризоване середовище біфідум агар та MRS, лактобактерій - середовище Лактобак-агар і середовище Блаурока в анаеробних умовах з використанням анаеростату з пакетами. Культувування бактерій групи Enterobacteriaceae (БГКП) здійснювали на середовищі Ендо, Плоскірєва. Для росту стафілококів використовували середовище жовчно-сольового агару (ЖСА), для виявлення стрептококів та мікроорганізмів з гемолітичними властивостями - м'ясопептонний агар (МПА) з додаванням цілісної крові. Ентерококи виявляли посівом на ентерококовий агар. Мікро- організми культивували у термостаті при температурі $37^{\circ} \mathrm{C}$ упродовж 24-72 год. Дріжджоподібні гриби роду Candida, плісеневі гриби вирощували на середовищі Сабуро в термостаті за температури $24^{\circ} \mathrm{C}$ упродовж 5 діб.

Культивування мікроорганізмів, дослідження їх ферментативних властивостей здійснювали згідно з нормативними документами та методичними рекомендаціями. 3 усіх типових колоній мікроорганізмів, які виросли на чашках Петрі, робили мазки, підсушували над полум'ям, фарбували та досліджували під мікроскопом.

Ідентифікацію чистих культур здійснювали шляхом верифікації морфологічних, тинкторіальних, культуральних властивостей мікроорганізмів з використанням матеріалів та ідентифікаційних таблиць видових ознак штамів, наведених у [7]. Фізіолого-біохімічні тести використовували як обов'язковий етап ідентифікації мікроорганізмів: їх поєднання $\epsilon$ індивідуальним для кожного роду мікроорганізмів.

Отримані дані виражали у відсотках, аналізували з використанням загальноприйнятих методів статистичної обробки результатів медико-біологічних досліджень, з використанням t-критерію Стьюдента та попередньою перевіркою нормальності розподілу.

Результати й обговорення. Бактеріологічне дослідження випорожнень прямого відділу товстої кишки тварин показало, що основними таксономічними групами, які формують склад нормобіоти фекального біотопу, $\epsilon$ біфідобактерії, лактобактерії, бактерії групи кишкових паличок, зокрема E. coli, ентерококи, стафілококи, які виявляли у випорожненнях 100,0 \% тварин. Частота виявлення пептострептококів та стрептококів коливалася в межах $33,3 \%-66,7 \%$ (середній показник $M=50,0 \%)$, протею - 16,7 \% - 50,0 \% ( $M=33,3 \%)$, грибів роду Candida - 16,7 \% - 33,3\% ( $M=29,2 \%)$, плісеневих грибів-0 \%-16,7 \% (M=8,4 \%) (табл. 1).

Таблиця 1. Частота виявлення видового складу мікрофлори вмісту товстої кишки у щурів при багаторазовій інгаляційній дії нітроксоліну

\begin{tabular}{|c|c|c|c|c|c|c|c|c|c|}
\hline \multirow[b]{2}{*}{$\begin{array}{c}\text { Період } \\
\text { обстеження }\end{array}$} & \multicolumn{9}{|c|}{ Мікроорганізми (частота виявлення у \%) } \\
\hline & 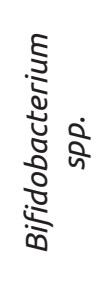 & 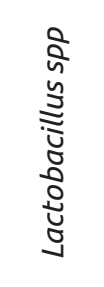 & 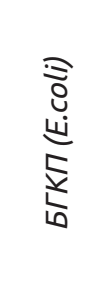 & 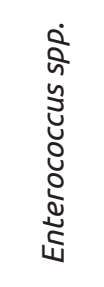 & 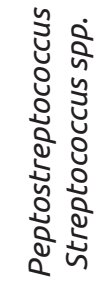 & 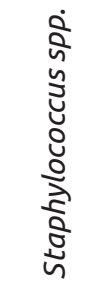 & 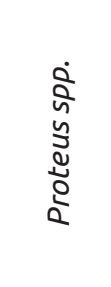 & 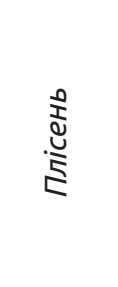 & 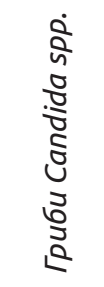 \\
\hline 1 & 2 & 3 & 4 & 5 & 6 & 7 & 8 & 9 & 10 \\
\hline \multicolumn{10}{|c|}{ Інтактні тварини (0,9 \% $\mathrm{NaCl}, \mathrm{n}=6)$} \\
\hline Фон & $6 / 100$ & $6 / 100$ & $6 / 100$ & $6 / 100$ & $3 / 50,0$ & $6 / 100$ & $2 / 33,3$ & $1 / 16,7$ & $2 / 33,3$ \\
\hline 2 тижні & $6 / 100$ & $6 / 100$ & $6 / 100$ & $6 / 100$ & $4 / 66,7$ & $6 / 100$ & $3 / 50,0$ & $0 / 0$ & $1 / 16,7$ \\
\hline 4 тижні & $6 / 100$ & $6 / 100$ & $6 / 100$ & $6 / 100$ & $2 / 33,3$ & $6 / 100$ & $2 / 33,3$ & $0 / 0$ & $2 / 33,3$ \\
\hline
\end{tabular}




\begin{tabular}{|c|c|c|c|c|c|c|c|c|c|}
\hline 1 & 2 & 3 & 4 & 5 & 6 & 7 & 8 & 9 & 10 \\
\hline $\begin{array}{l}\text { Віднов. пер. } \\
\text { (1 міс.) }\end{array}$ & $6 / 100$ & $6 / 100$ & $6 / 100$ & $6 / 100$ & $3 / 50,0$ & $6 / 100$ & $1 / 16,7$ & $1 / 16,7$ & $2 / 33,3$ \\
\hline \multicolumn{10}{|c|}{ Перша дослідна група (5 мг/м³, n=8) } \\
\hline Фон & $8 / 100$ & $8 / 100$ & $8 / 100$ & $8 / 100$ & $4 / 50,0$ & $8 / 100$ & $4 / 50,0$ & $2 / 25,0$ & $2 / 25,0$ \\
\hline 2 тижні & $8 / 100$ & $8 / 100$ & $8 / 100$ & $8 / 100$ & $5 / 62,5$ & $8 / 100$ & $3 / 37,5$ & $0 / 0$ & $3 / 37,5$ \\
\hline 4 тижні & $8 / 100$ & $8 / 100$ & $8 / 100$ & $8 / 100$ & $5 / 62,5$ & $8 / 100$ & $2 / 25,0$ & $1 / 12,5$ & $2 / 25,0$ \\
\hline $\begin{array}{l}\text { Віднов. пер. } \\
\text { (1 міс.) }\end{array}$ & $8 / 100$ & $8 / 100$ & $8 / 100$ & $8 / 100$ & $4 / 50,0$ & $8 / 100$ & $3 / 37,5$ & $0 / 0$ & $2 / 25,0$ \\
\hline \multicolumn{10}{|c|}{ Друга дослідна група (15 мг/м³, $\mathrm{n=8})$} \\
\hline Фон & $8 / 100$ & $8 / 100$ & $8 / 100$ & $8 / 100$ & $5 / 62,5$ & $8 / 100$ & $2 / 25,0$ & $1 / 12,5$ & $3 / 37,5$ \\
\hline 2 тижні & $8 / 100$ & $8 / 100$ & $8 / 100$ & $8 / 100$ & $4 / 50,0$ & $8 / 100$ & $4 / 50,0$ & $2 / 25,0$ & $3 / 37,5$ \\
\hline 4 тижні & $8 / 100$ & $8 / 100$ & $8 / 100$ & $8 / 100$ & $3 / 37,5$ & $8 / 100$ & $4 / 50,0$ & $4 / 50,0$ & $4 / 50,0$ \\
\hline $\begin{array}{l}\text { Віднов. пер. } \\
\text { (1 міс.) }\end{array}$ & $8 / 100$ & $8 / 100$ & $8 / 100$ & $8 / 100$ & $4 / 50,0$ & $8 / 100$ & $4 / 50,0$ & $3 / 37,5$ & $4 / 50,0$ \\
\hline \multicolumn{10}{|c|}{ Трета дослідна група (45 мг/м³, n=8) } \\
\hline Фон & $8 / 100$ & $8 / 100$ & $8 / 100$ & $8 / 100$ & $4 / 50,0$ & $8 / 100$ & $3 / 37,5$ & $2 / 25,0$ & $2 / 25,0$ \\
\hline 2 тижні & $8 / 100$ & $8 / 100$ & $8 / 100$ & $8 / 100$ & $3 / 37,5$ & $8 / 100$ & $4 / 50,0$ & $4 / 50,0$ & $4 / 50,0$ \\
\hline 4 тижні & $8 / 100$ & $8 / 100$ & $8 / 100$ & $8 / 100$ & $2 / 25,0$ & $8 / 100$ & $6 / 75,0$ & $5 / 62,5$ & $6 / 75,0$ \\
\hline $\begin{array}{l}\text { Віднов. пер. } \\
\text { (1 міс.) }\end{array}$ & $8 / 100$ & $8 / 100$ & $8 / 100$ & $8 / 100$ & $3 / 37,5$ & $8 / 100$ & $5 / 62,5$ & $5 / 62,5$ & $5 / 62,5$ \\
\hline
\end{tabular}

у процесі проведення експериментальних досліджень встановлено, що при багаторазовій інтраназальній дії нітроксоліну в концентраціях $5 \mathrm{Mr} / \mathrm{M}^{3}, 15 \mathrm{Mr} / \mathrm{M}^{3}, 45 \mathrm{Mr} / \mathrm{M}^{3}$ показник частоти виявлення домінуючих бактеріальних популяцій: біфідо-, лактобактерій, БГКП, ентерококів і стафілококів залишався незмінним - 100,0%. Для інших бактеріальних груп фекального біотопу спостерігали певні відхилення в бік зростання чи зниження частоти виявлення, залежно від концентрації діючого чинника.

Слід зазначити, що концентрація нітроксоліну $5 \mathrm{Mr} / \mathrm{M}^{3}$ не викликала змін у структурі мікробіоти

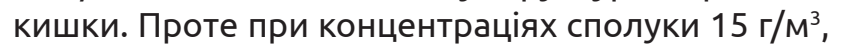
$45 \mathrm{mr} / \mathrm{M}^{3}$ на 4 тиждень експерименту у випорожненнях щурів відбувається зростання кількості умовно-патогенних штамів, порівняно з фоновими показниками. Збільшується частота виявлення протею в 2,0 рази ( $<<0,05)$, грибів роду Candida в 1,3 раза $(p>0,05)$ і 3,0 рази $(p<0,01)$, плісеневих грибів - у 4,0 рази $(p<0,01)$ і 2,5 разів $(p<0,05)$ та знижується у 1,7 рази $(p>0,05)$ і 2,0 рази $(p<0,05)$ відповідно виявлення пептострептококів і стрептококів.

Через місяць відновного періоду, частота виявлення протею, грибів роду Candida, плісеневих грибів у тварин другої та третьої груп практично утримувалася на рівні показників 4 тижня експерименту. Лише у тварин з хронічним впливом концентрації нітроксоліну $15 \mathrm{Mr} / \mathrm{M}^{3}$ спостерігали повернення частоти виявлення пептострептококів i стрептококів до фонових величин, а у щурів з кон- центрацією впливу лікарського засобу $45 \mathrm{mг} / \mathrm{M}^{3}$, у відновний період виявлення даного виду бактерій зростало в 1,5 раза, однак було на 12,5 \% нижчим від вихідних значень.

Висновки. У щурів самок основними таксономічними групами, які формують склад нормобіоти фекального біотопу прямого відділу товстої кишки $\epsilon$ біфідо-, лактобактерії, бактерії групи кишкових паличок, ентерококи, стафілококи - з частотою виявлення у 100,0 \% тварин. Концентрація

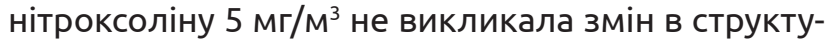
рі мікробіоти кишки.

Багаторазовий інгаляційний вплив нітроксоліну у концентраціях $15 \mathrm{Mr} / \mathrm{M}^{3}, 45 \mathrm{Mr} / \mathrm{M}^{3}$ обумовлював структурні зміни в системі екомікроценозу вмісту прямого відділу товстої кишки, викликав зростання частоти виявлення у структурі фекального біотопу умовно-патогенних штамів та зниження пептострептококів і стрептококів.

Наприкінці відновного періоду частота виявлення протею, грибів роду Candida, плісеневих грибів у фекальному біотопі щурів другої (15 мг/м³) та

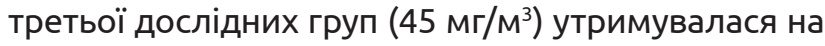
рівні показників 4 тижня експерименту, виявлення пептострептококів і стрептококів поверталося до фонових показників лише у тварин другої групи.

Концентрація нітроксоліну 15 мг/м³ , яка при багаторазовій інгаляційній дії сполуки викликає у щурів дисбактеріоз прямого відділу товстої кишки, $\epsilon$ пороговою для цього ефекту.

Перспективи подальших досліджень. Планується детальніше вивчення характеру дисбак- 
Огляди літератури, оригінальні дослідження, погляд на проблему, ювілеї

теріозів у експериментальних тварин внаслідок багаторазового інгаляційного впливу нітроксоліну, зокрема зміни структури й кількісного складу нормобіоти просвіту товстої кишки, колонізацій- ної активності бактеріальних груп усередині певного мікробного конгломерату, співвідношення питомої ваги облігатної та умовно-патогенної флори.

\section{ЛІТЕРАТУРА}

1. Effects of antibiotics on human microbiota and subsequent disease / K. M. Keeney, S. Yurist-Doutsch, M. C. Arrieta, B. B. Finlay // Annual Review of Microbiology. - 2015. - No. 68. - P. 217-235.

2. Walter J. The human gut microbiome: Ecology and recent evolutionary changes / J. Walter, R. Ley // Annual Review of Microbiology. - 2011. - No. 65. - P. 411-429.

3. Обґрунтування гранично допустимих концентрацій лікарських засобів у повітрі робочої зони і в атмосферному повітрі населених місць : метод. вказівки № 544, затверджені наказом МОЗ України від 21.10.2005 р. C. 19.

4. Кузьмінов Б. П. Обгрунтування орієнтовно безпечного рівня впливу нітроксоліну у повітрі робочої зони виробничих приміщень / Б. П. Кузьмінов, Т. С. За- зуляк, Г. І. Яськів, В. А. Туркіна // Сучасні проблеми токсикології, харчової та хімічної безпеки. - 2016. - № 3 (75). - С. 39-42.

5. Порядок проведення науковими установами дослідів, експериментів на тваринах / Офіційний вісник України. - Офіц. Вид. - 2012 р. - № 24. - С. 82.

6. Готування розчинів реактивів, фар6, індикаторів і поживних середовищ, які застосовують у мікробіологічному аналізуванні: ДСТУ 5093:2008. - [Чинний від 2010-05-31]. - Київ : Держспоживстандарт України, 2010. - 28 с. - (Національний стандарт України).

7. Определитель бактерий Берджи: в 2-х томах. Т.1 / Под ред. Хоулта Дж., Крига Н., Снита П., Стейли Дж., Уилльямса С.; пер. с англ. под ред. Заварзина Г. А. - 9-е изд. - М. : Мир, 1997. - 432 с.

\title{
REFERENCES
}

1. Keeney, K.M., Yurist-Doutsch, S., Arrieta, M.C., \& Finlay, B.B. (2015). Effects of antibiotics on human microbiota and subsequent disease. Annual Review of Microbiology, 68, 217-235.

2. Walter, J., \& Ley, R. (2011). The human gut microbiome: Ecology and recent evolutionary changes. Annual Review of Microbiology, 65, 411-429.

3. (2005). Obhruntuvannia hranychno dopustymykh kontsentratsii likarskykh zasobiv u povitri robochoi zony i v atmosfernomu povitri naselenykh mists. Metod. Vkazivky [Justification of the maximum permissible concentrations of drugs in the air of the working zone and in the atmospheric air of the inhabited places. Method. recommendations]. Kyiv: MOZ Ukrainy [in Ukrainian].

4. Kuzminov, B.P., Zazuliak, T.S., Yaskiv, H.I., \& Turkina, V.A. (2016). Obhruntuvannia oriientovno bezpechnoho rivnia vplyvu nitroksolinu u povitri robochoi zony vyrobnychykh prymishchen [Justification of the roughly safe level of nitroxolin exposure in the air of the working area of in-

dustrial premises]. Suchasni problemy toksykolohii, kharchovoi ta khimichnoi bezpeky - Modern Problems of Toxicology, Food and Chemical Safety, 3 (75), 39-42 [in Ukrainian].

5. (2012). Poriadok provedennia naukovymy ustanovamy doslidiv, eksperymentiv na tvarynakh [The order of the scientific institutions to conduct experiments, experiments on animals]. Ofitsiinyi visnyk Ukrainy. Ofits. Vyd. - Official Journal of Ukraine. Official Publication, 24, 82 [in Ukrainian].

6. (2010). Hotuvannia rozchyniv reaktyviv, farb, indykatoriv i pozhyvnykh seredovyshch, yaki zastosovuiut u mikrobiolohichnomu analizuvanni: DSTU 5093:2008 [Preparation of solutions of reagents, paints, indicators and nutrient media used in microbiological analysis: DSTU 5093:2008]. Kyiv: Derzhspozhyvstandart Ukrainy [in Ukrainian].

7. Hoult, Dzh., Krig, N., Snit, P., Steyli, Dzh., \& Uillyams, S. (1997). Opredelitel bakteriy Berdzhi: v 2-h tomah. T.1. Per. s angl. [Determinant of bacteria Berdzhi: in 2 volumes. V.1. Transl. from English]. Moscow: Mir [in Russian].

\section{ОЦЕНКА ВИДОВОГО СОСТАВА МИКРОФЛОРЫ СОДЕРЖИМОГО ТОЛСТОЙ КИШКИ У КРЫС ПРИ МНОГОКРАТНОМ ИНГАЛЯЦИОННОМ ВОЗДЕЙСТВИИ НИТРОКСОЛИНА}

\author{
๑Г. И. Яськив, Б. П. Кузьминов, И. Л. Платонова, И. А. Руда \\ Львовский национальный медицинский университет имени Данила Галицкого
}

РЕЗЮМЕ. Важным в схеме исследований по гигиеническому обоснованию гигиенических регламентов допустимого содержания лекарственных средств в воздухе рабочей зоны фармацевтических предприятий является определение параметров токсичности, аллергического, эмбриотоксического, дисбиотического действия.

Цель - оценка видового состава микрофлоры содержимого прямого отдела толстой кишки у крыс при многократном ингаляционном воздействии нитроксолина.

Материал и методы. Дисбиотическое действие нитроксолина изучали на крысах, которых в течение 30 дней

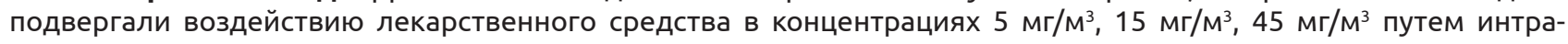
назального введения. 
Огляди літератури, оригінальні дослідження, погляд на проблему, ювілеї

Результаты. Доминантными представителями нормобиоты фекального биотопа являются бифидобактерии, лактобактерии, бактерии группы кишечных палочек (БГКП), в частности E. coli, энтерококки, стафилококки, которые присутствовали в испражнениях 100,0 \% животных. Частота встречаемости пептострептококков и стрептококков колебалась в пределах 33,3 \% - 66,7 \%, протея - 16,7 \% - 50,0 \%, грибов рода Сandida - 16,7 \% - 33,3 \%,

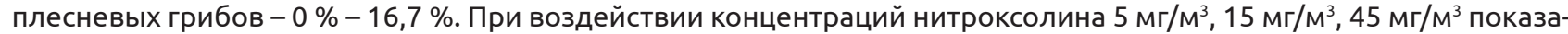
тель частоты встречаемости для доминирующих бактериальных популяций: бифидо-, лактобактерий, БГКП, энтерококков и стафилококков оставался прежним - 100,0 \%. Нитроксолин в концентрации 5 мг/м² не вызывал

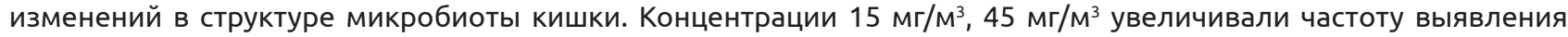
условно-патогенных штаммов и снижение - пептострептококков и стрептококков. В конце восстановительного периода частота встречаемости протея, грибов рода Candida, плесневых грибов в фекальном биотопе крыс вто-

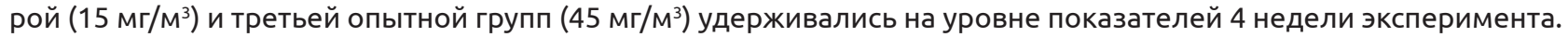

Выводы. Многократное ингаляционное действие нитроксолина в концентрации $15 \mathrm{Mr} / \mathrm{M}^{3}$ вызывает дисбактериоз толстого кишечника у крыс, при этом концентрация 15 мг/м³ является пороговой для этого эффекта.

КЛЮЧЕВЫЕ СЛОВА: нитроксолин; ингаляционное воздействие; микробиоценоз толстой кишки.

\title{
ESTIMATION OF THE SPECIES COMPOSITION OF THE MICROFLORA OF THICK INTESTINE IN THE RATS AT THE MULTIPLE INHALATION REACTION OF NITROXOLINE
}

\author{
๑G. I. Yaskiv, B. P. Kuzminov, I. L. Platonova, I. A. Ruda \\ Danylo Halytskyi Lviv National Medical University
}

SUMMARY. The establishment of parameters of toxicity, allergic, embryotoxic, dysbiotic action is an important in the scheme of research on the hygienic justification of hygienic regulations for the admissible content of drugs in the air of the working zone of pharmaceutical enterprises.

The aim - evaluation of the microflora species composition of the direct colon in rats with repeated inhalation exposure to nitroxoline.

Materials and Methods. The dysbiotic effect of nitroxolin was studied in rats, which were exposed to the drug at concentrations of $5 \mathrm{mg} / \mathrm{m}^{3}, 15 \mathrm{mg} / \mathrm{m}^{3}, 45 \mathrm{mg} / \mathrm{m}^{3}$ for 30 days by intranasal administration.

Results and Discussion. The dominant representatives of the fecal biotope normobites are Bifidobacteria, Lactobacteria, bacteria of the intestinal sticks, in particular E. coli, Enterococcus, and Staphylococcus, which were detected in the excrements of $100.0 \%$ of animals. The frequency of occurrence of Peptostreptococcus and Streptococcus ranged from $33.3 \%-66.7 \%$, Protea - 16.7\% - $50.0 \%$, Candida fungi $-16.7 \%-33.3 \%$, Mold - $0 \%-16,7 \%$. When exposed to nitroxoline concentrations of $5 \mathrm{mg} / \mathrm{m}^{3}, 15 \mathrm{mg} / \mathrm{m}^{3}, 45 \mathrm{mg} / \mathrm{m}^{3}$, the prevalence rate for the dominant bacterial populations: Bifidobacteria, Lactobacillus, bacteria in the E. coli group, Enterococcus and Staphylococcus remained unchanged in $100.0 \%$. Nitroxolin at a concentration of $5 \mathrm{mg} / \mathrm{m}^{3}$ did not cause changes in the structure of the intestinal microbiota. Concentrations of $15 \mathrm{mg} / \mathrm{m}^{3}, 45 \mathrm{mg} / \mathrm{m}^{3}$ caused an increase in the frequency of detection of opportunistic strains and reduction of Peptostreptococcus and Streptococcus. At the end of the recovery period, the frequency of occurrence of Proteus, Candida fungi, Mold fungi in the fecal biotope of rats of the second $\left(15 \mathrm{mg} / \mathrm{m}^{3}\right)$ and third experimental group $\left(45 \mathrm{mg} / \mathrm{m}^{3}\right)$ was kept at the level of 4 weeks of the experimental level.

Conclusions. Multiple inhalation action of nitroxolin in concentration $15 \mathrm{mg} / \mathrm{m}^{3}$ causes dysbiosis of the large intestine in rats, with a concentration of compound of $15 \mathrm{mg} / \mathrm{m}^{3}$ is a threshold for this effect.

KEY WORDS: nitroxoline; inhalation effect; colon microbiocenosis. 